MAGPIE GEESE by Peter Scott, reproduced from Waterfowl of the World by Jean Delacour with paintings by Sir Peter Scott. Country Life has produced a straight reprint of this standard work ( $\$ 40.00$ in case). In these four volumes a major bird artist has married his art to his lifetime study of a bird grouping. The important additions are two short personal paragraphs on the author and the artist, and, in Volume 4, 'New General Corrections and Additions (1972)'; these follow the corrections and additions in the original Vol. 4, which, appearing in 1964, lagged ten years behind the original Vol. 1.

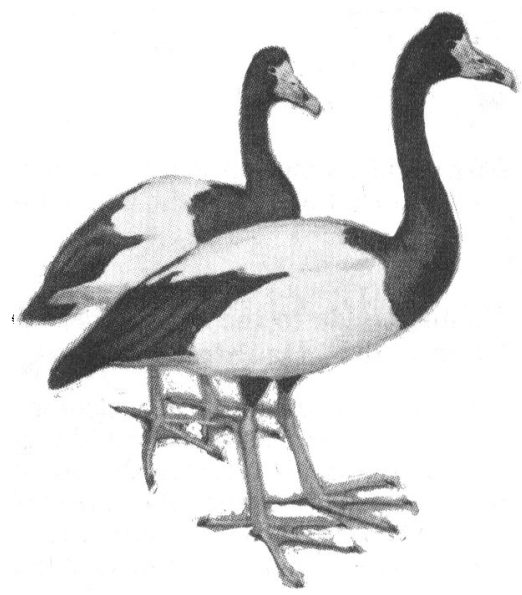

material to give an informative diagrammatic presentation. The general design is imaginative.

The approach is mainly geographical and ecological. The main part of the book traverses in turn the faunal regions of the world, and within each of these the main habitats and the birds characteristic of them. It is unfortunate, however, that the recognised scientific term 'region', which has served for over a century since the concept was originally formulated, should have here been irresponsibly replaced by 'realm' (which has had another usage in zoogeography). Particular notice is taken of species that have become extinct within historic times or are now endangered. A final section gives summary information about the different families of birds, with drawings of representative species.

A. LANDSBOROUGH THOMSON

\title{
Wild Flowers of Britain and Northern Europe, by Richard Fitter, Alastair Fitter and Marjorie Blamey. Collins $£ 1.60$
}

This handy textbook compresses a wealth of information of particular value to the botanical beginner, for whom the main key is specially designed. The emphasis is on identification, for which simplicity and clarity are essential. A practical key such as this one, based on physical features easily recognised by the naked eye and avoiding botanical jargon, is what is needed.

The book's scope extends to all trees, shrubs and flowering plants - 'flowering' is the operative word - growing wild in the British Isles, including Ireland, and Northern Europe from the Alps, excluding Switzerland, to the Arctic, including Iceland. Consequently, grasses, sedges, rushes, ferns and horsetails are omitted.

The excellence of delineation of Marjorie Blamey's illustrations renders detailed description unnecessary. The orchids deserve special mention, their identity virtually unmistakeable by the inclusion of a fiower of each species precisely depicted.

More than a thousand species are illustrated in colour, mostly life size. Generally they are superb, but some suffer in reproduction - no fault of the artist - from a tendency to be too pallid, and the yellow coloration may be either absent or faint. A minor criticism concerns the bogbean illustration which shows too much leaf, for it is the upright flower spikes of this attractive water plant that are so conspicuous.

The text describes distribution and the habitat but omits specific localities. All items on the British List are marked with an asterisk. Text abbreviations and symbols are lucidly explained. The simple keys (except the waterweeds) are illustrated in colour and based primarily on flower design and, for the trees, leaf shape. A map shows the principal limestone/chalk areas. 'Take the book to the plant and not the plant to the book' is a plea that warrants repetition - a plant plucked may be a plant lost for ever.

Highly recommended for all those interested in wild flowers, this handbook is a 
bargain at its modest price, and the knowledge it imparts stupendous - surely it is a must for all lovers of the countryside.

C. R. S. PITMAN

\section{Collins Guide to the Sea Fishes of Britain and North-Western Europe, by B. J. Muus and P. Dahlstrom. Collins, $£ 2.95$}

It is pleasant to be able to welcome the arrival of a book which is actually cheaper to buy than its appearance would suggest, despite copious colour illustrations. These, by the distinguished Danish illustrator Preben Dahlstrom, are undoubtedly the book's main attraction; they are some of the best of European fishes ever produced - accurate, correctly coloured, and suggesting the living fish. His presentation too is interesting. The whole fish is represented, and little vignettes show hooks, the species' food, the canned product, and occasionally witty little sketches, as of the wistful looking cat beneath a huge tunny!

As a result Bent Muus's text, ably translated by Dr Gwynne Vevers, is rather overshadowed but more space has been found for it than in the original Danish edition (by using smaller type), and the species accounts are longer. Dr Vevers has also updated the scientific nomenclature. Two minor errors here are Gadus morrhua, instead of G. morhua, for the cod and Gobius minutus for the very abundant sand goby where the Danish edition gave it (correctly) as Pomatoschistus minutus.

As a guide to the fish fauna of the coasts of Denmark this is as excellent a book as one could ask for, and it serves very well for North Sea fishes. But to claim that it is a valid guide for North-west Europe is a false pretence, for which the Danish publishers are responsible.

The four pages devoted to gobies show six species dealt with in detail and three others merely mentioned - but at least 16 species are found round the British Isles. Montagu's blenny, common in the western English Channel and on the western Irish coast, is dismissed in two lines of text, and the illustration is a parody of this beautiful little fish, owing a lot to Francis Day's (1881) widely-copied but inaccurate illustration. These examples could be multiplied many times over, but they serve to show that the book is far from adequate as a guide to the British fish.

A number of commercially exploited crustaceans and molluscs are included, also with excellent illustrations, and the book concludes with an account of the history of fishing and the development of fishing techniques - both interesting, and models of compression.

ALWYNE WHEELER

\section{Creating Habitat}

In The Sevenoaks Gravel Pit Reserve, (obtainable from Merriewood House, St Botolph's Road, Sevenoaks, Kent, 62p.) Jeffery Harrison describes a remarkable achievement (in which he was prime mover) in creating wildlife habitat - a conservation technique that becomes increasingly important as wild habitat, especially wetlands, disappear. With the agreement of the gravel-pit owners, volunteers started work in 1956, creating islands, sheltered bays and spits, and planting cover, with the result that - to take just one set of figures - the annual wildfowl usage in wildfowl days' for dabbling and grazing ducks went up from 6162 in $1956 / 57$ to 79,244 in 1973/74. Interesting rarities here included ospreys, hoopoes, waxwings, water pipit and whooper swans. All this in the midst of suburbia.

The operation was a joint one by the Wildfowlers' Association of Great Britain and Ireland and the Wildfowl Trust, and shows how conservationists and industry can co-operate. The rather nervous reaction of industry is revealed in the foreword by Lord Beeching, Chairman of Redlands, the owners, when he praises 'the reasonableness of the ardent conservationists who run this reserve'. Was he surprised? 